DOI: https://doi.org/10.24297/ijmit.v15i.8749

\title{
The Influence of Value-Co-Creation on Brand Equity: An Empirical Study in Saudi Arabia
}

\author{
Salwa Fouad Taher', Soad Abdullah Almeshal ${ }^{2}$ \\ ${ }^{1}$ Lecturer and PhD student. Marketing Department, King Saud University, Saudi Arabia \\ ${ }^{2}$ Assistant Professor. Marketing Department, King Saud University, Saudi Arabia \\ 1Staher1@ksu.edu.sa 2salmeshal@ksu.edu.sa
}

\begin{abstract}
The current study aims to explore the influence of value co-creation on brand equity in a Saudi Arabia context. An attempt to illustrate the factors influencing brand equity from a consumer's perspectives as a result of changing customer's interests and lifestyle. Consumer's co-creation of value is powerful in understanding consumer behavior at its impact on brand equity. This paper has made an applied attempt in Saudi Arabia to study the mediation effect of positive e-WOM on value co-creation and brand equity, which adds to the knowledge line in the digital marketing discipline.
\end{abstract}

Keywords: Value-Co-Creation, Positive E-WOM, and Brand Equity

\section{Introduction}

Building strong brands is considered as important phenomena. Both academics and practitioners gave brand building a huge attention. Since brand equity building is considered an important part of brand building (Keller, 2008), research indicated that almost all marketing activities work successfully in order to build and manage brand equity (Aaker,1991; Keller,1993; Yoo \& Donthu,2001).Therefore, organizations can gain a competitive advantages through having and maintaining strong brands (Keller, 1993,2008; Aaker, 1996a).

Having a strong brand with a positive brand equity will provide more powerful communications (Netemeyer et al., 2004; Buil et al., 2008, 2013). Today the Internet as a major part of our lives has changed our ways of communications. The use of the Internet through the different social media platforms has enabled its users to see each other, hear each other and share their interests. This new way of connection is changing the way people communicate.

There is a strong association between the use of social networks and the value of customers and customers' relationship development, trust and loyalty, and service assessment (Wigmo et al. 2010; Hu 2013; Saleh, 2016). Therefore, organizations are interacting and connecting with consumers through setting up their own websites based on social media platforms. (2013; Hajli, Sims, Featherman, \& Love, 2014a; Hajli, Lin, Featherman, \& Wang, 2014b).

\section{Problem Statement}

The present study intends to find the mediation effect of positive e-WOM on value-co-creation and brand equity from consumers' perspectives.

This study will shed light on the influence of value co-creation on brand equity as an empirical study among Saudi Arabia. It is expected that the study can provide evidence that will help organizations to better understand the importance of value, brand equity and e-WOM on social media. It is also expected that this study can enrich previous research in customer value co-creation e-WOM and brand equity in Saudi context. 


\section{Literature Review}

\subsection{Value co-creation}

Value co-creation was defined by Prahalad and Ramaswamy (2004a) as "the process where the consumer and the firm are intimately involved in jointly creating value that is unique to the individual consumer and sustainable to the firm" Prahalad and Ramaswamy (2004) argued that the value of a product or a service is not created solely by the manufacturer/supplier, but by both the manufacturer/supplier and the consumer of the product or service provided by the manufacturer/supplier. Payne et al. (2008) argues that consumers' emotional engagement with a brand engages consumers to value co-creation through the learning process which help customers to gain better understanding about the firm and engage in the product or service provided by that firm. More than that, value co-creation is that a supplier provides a product as an input of value co-creation and a consumer co-creates the value of the product or service by applying skills and knowledge in using the product (Fellesson \& Salomonson, 2016; Vargo et al., 2008). Otchere and Yun (2019) stated that value co-creation can creates positive long term relationships between an organization and its customer

\subsection{Positive E-WOM}

Even though E-WOM is considered a new version of the traditional WOM few differences were addressed by Dellarocas, (2003). First, E-WOM has a lower- cost but a large- scale networks than the traditional WOM. Second, the ability of monitoring E-WOM since individuals' communications are done through internet and social platforms which is hard to be done with WOM since its considered verbal communication (Kotler \& Keller, 2012). Third, WOM reaches one person at a time while E-WOM reaches a large number of individuals at a time .Finally, E-WOM user identities could be anonymous or inaccurate which is not the case in WOM. Haywood (1989, p.58) presented WOM as a formal way of communication and defined WOM as "a process that is often generated by a company's formal communications and the behavior of its representatives." According to Anderson (1998, p. 6) "Word of mouth refers to information communications between private parties concerning evaluations of goods and services." Positive E-WOM has an influence on product evaluation and can participate in building brands (Litvin et al., 2008). Dellarocas' (2003) indicates that E-WOM has valuable implications for brand building, customer relationship management, and product development. Therefore, the study will focus on positive E-WOM.

\subsection{Brand Equity}

According to (Keller, 2008) Building brand equity is considered an important part of brand building. Therefore, the different marketing activities in almost every organization try to build and manage brand equity (Aaker, 1991; Keller, 1993; Yoo \& Donthu, 2001). Academic marketing professionals and business practices give brand equity attention since this concept help organizations gain a competitive advantages through strong brands (Keller, 1993, 2008; Aaker, 1996a). Research indicated that there are many advantages associated with positive brand equity. Powerful communication effectiveness and higher consumer preferences and purchase intentions are all examples of these advantages (Keller, 1993; Cobb-Walgren et al., 1995; Netemeyer et al., 2004; Buil et al., 2008, 2013). As this study focus on consumer-based brand equity (CBBE), the two main frameworks that conceptualize CBBE are those of Aaker (1991, 1996b) and Keller (1993). Aaker (1991, 1996b) defines CBBE as a set of assets and liabilities linked to a brand, its name and symbol that add to or subtract from the value provided by a product or service to the customers. CBBE is a multidimensional concept including four core dimensions - brand awareness, perceived quality, brand associations, and brand loyalty. Keller (1993) Defines CBBE as "the differential effect of brand knowledge on consumer response to the marketing of a brand." Keller's conceptualization focusses on brand knowledge which involves two components: brand awareness (recall and recognition) and brand image (a combination of favorability, strength, and uniqueness of brand associations). 
The basic consumer related dimensions central to brand equity that will be studied in the present research are brand awareness, perceived quality, brand personality (since it is included in brand associations) based on the review of past literature (Aaker (1991, 1996b); Keller, 1993; Cobb-Walgren et al., 1995; Yoo and Donthu (2001); Pappu et al. (2005); Buil et al., 2008, 2013).

\subsubsection{Brand Awareness}

According to Keller (1993) brand awareness is consisting of both brand recognition and brand recall: brand recall refers to consumers' ability to retrieve the brand from memory; while brand recognition is the basic and first step in brand communication. This construct is related to the strength of a brand's presence in consumers' minds (Hakala et al., 2012).

\subsubsection{Perceived Quality}

Perceived Quality is defined as "the consumer's judgment about a product's overall excellence or superiority" (Zeithaml, 1988, p. 3). From that it can be considered that the perceived quality is the consumers' subjective evaluations which depend on their perceptions that will provide consumers with a reason to buy and will also create a basis for brand differentiation and extension (Aaker, 1991; Pappu et al., 2005).

\subsubsection{Brand Loyalty}

Brand loyalty is defined as "a deeply held commitment to rebuy a preferred brand or service consistently in the future, thereby causing repetitive same brand or same brand set purchasing, despite situational influences and marketing efforts having the potential to cause switching behaviour" (Oliver, 1999, p. 34). Brand loyalty is considered as one of the most important determinants of brand equity (Aaker, 1991).

Few researches investigated the E-WOM influence on brand equity dimensions .For example; Thomas et al. (2006) concluded that customers' exchange of technical knowledge influences the customer's perception of product value and probability of recommending it. While Severi et al. (2014) and Eze, Nnabuko and Etuk (2014) indicated that there is a positive relation between E-WOM and brand equity. Bambauer-Sachse and Mangold, (2011) concluded that negative E-WOM have considerable detrimental effects on consumer-based brand equity and thus lead to a significant brand equity dilution. Therefore it can be argued that positive EWOM can influence brand equity dimensions which will influence brand equity.

\section{Research Methodology}

\subsection{Research Model}

This study will be based on the following proposed model

Brand Equity

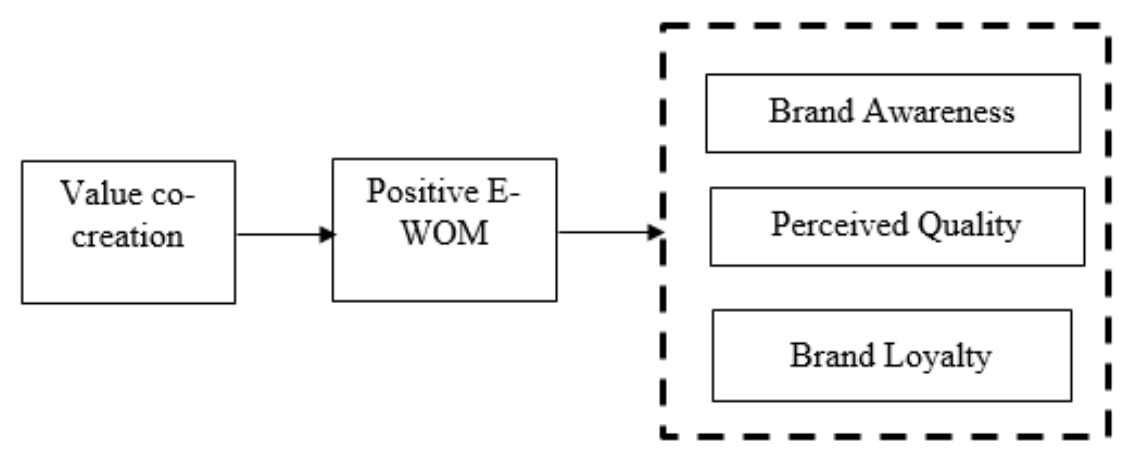

Figure 1: Research Model 


\subsection{Research Hypotheses}

H1: Value-co creation has a significant positive relationship with positive E-WOM.

H2: Positive E-WOM mediates the relation between Value-co creation and brand equity.

H2a: Positive E-WOM has a significant positive relationship with brand Awareness.

H2b: Positive E-WOM has a significant positive relationship with brand perceived quality.

H2c: Positive E-WOM has a significant positive relationship with brand loyalty.

\subsection{Sampling Framework}

The population of this study is all people who are using social media platform to search for information regarding international fast fashion brand in Saudi Arabia. Convenience sample will be used as a nonrandom method in order to achieve the required sample size via online survey websites.

The data was collected using electronic survey from consumers who are using online shopping. The data collection process lasted for 10 weeks. A total of 530 surveys were distributed, of which a total of 530 were returned (a response rate of 57\%). After eliminating, 301 responses were used due to insincerity or incompleteness through data.

\subsection{Statistical Analysis}

Descriptive analysis was used to find demographic characteristics of the sample, as well as Cronbach's alpha to test reliability. Convergent validity and Discriminant validity was also tested .While structural equation modeling was used to test the hypotheses.

\subsection{Instrument design}

The questionnaire used for data collection has been adopted from prior research Nine items were adopted from Yi, Y., \& Gong, T. (2013) to measure value co-creation. To measure the four dimensions of brand equity four items will be adapted from Buil et al. (2008), Yoo and Donthu (2001), and Tong and Hawley (2009) to measures brand awareness. Three items of perceived quality will be adapted from Buil et al. (2008), Yoo and Donthu (2001), and Netemeyer et al. (2004). Three items will also be used for measuring brand loyalty which are adapted from Buil et al. (2008), and Yoo and Donthu (2001).Finally, the scale to measure positive E-WOM will be adopted from Goyette et.al (2010) research which consists of four items. A demographic section will also be added at the questionnaire. The initial questionnaire draft will be developed in English language then the questionnaire will be translated into Arabic language. Back translation was made to ensure face validity.

\section{Results}

The sample included 301 respondents, 288 were Saudi and only 13 were from other nationalities. Both genders were represented in the sample while the majority of the sample was female with a percentage of $87.7 \%$ and $12.3 \%$ male. Most of the respondents were single with a percentage of $56.5 \%$ while $38.5 \%$ were married. The average household income of the respondent varied. Respondents with income ranging between 20,001-30000 RS account for $17.9 \%$ of the sample, while respondents with income of 10,000 RS or less account for $23.9 \%$ of the sample, followed by respondents with income ranging between 10,001 -20,000 RS with a percentage of $27.9 \%$, while $30.2 \%$ of the respondents' income was 30,001 RS or more. $44.9 \%$ of the respondents were from the age group of 20-30 years old, $27.2 \%$ were from the age group of 31-40 years old, and $13.6 \%$ were under 20 years old. 190 of the respondents hold a Bachelor's degree while 63 finished high school. Table.1 illustrates the frequencies and percentages of the demographics. 
Table.1 Demographics Characteristics of the Study Sample

\begin{tabular}{|c|c|c|c|}
\hline \multirow[b]{2}{*}{ Demographics } & \multirow[b]{2}{*}{ Category } & \multicolumn{2}{|c|}{ Frequency } \\
\hline & & $n=301$ & Percent\% \\
\hline \multirow[t]{2}{*}{ Gender } & Female & 264 & 87.7 \\
\hline & Male & 37 & 12.3 \\
\hline \multirow[t]{2}{*}{ Nationality } & Other & 13 & 4.3 \\
\hline & Saudi & 288 & 95.7 \\
\hline \multirow[t]{5}{*}{ Age } & $20-30$ & 135 & 44.9 \\
\hline & $31-40$ & 82 & 27.2 \\
\hline & $41-50$ & 28 & 9.3 \\
\hline & above 50 years old & 15 & 5.0 \\
\hline & Under 20 years old & 41 & 13.6 \\
\hline \multirow[t]{5}{*}{ Education } & Bachelor's degree & 190 & 63.1 \\
\hline & Doctorate degree & 3 & 1.0 \\
\hline & High school & 63 & 20.9 \\
\hline & Master degree & 38 & 12.6 \\
\hline & Other & 7 & 2.3 \\
\hline \multirow[t]{3}{*}{ Current status } & Married & 116 & 38.5 \\
\hline & Other & 15 & 5.0 \\
\hline & Single & 170 & 56.5 \\
\hline \multirow[t]{4}{*}{ Income } & 10,000 RS or less & 72 & 23.9 \\
\hline & $10,001-20,000 \mathrm{RS}$ & 84 & 27.9 \\
\hline & $20,001-30000 \mathrm{RS}$ & 54 & 17.9 \\
\hline & 30,001 RS or more & 91 & 30.2 \\
\hline
\end{tabular}

Structural Equational Modeling (SEM) - AMOS- was used to analyze the data two steps process was followed according to Gerbing and Anderson (1988). First, the measurement model was assessed to check the reliability and validity of the model and scales. Cronbach's alpha was calculated using IBM SPSS for each measurement 
within a dimension to assess the internal consistency of the measurement in order to test its reliability. A cutoff value for Cronbach's alpha is acceptable when it is at least .70 (Nunnally \& Bernstein, 1994). The measures of reliability tested by Cronbach's alpha are presented in Table 2. Cronbach's alpha coefficient scores ranged from .869 to .928 across all factors. The results demonstrate a good level of internal consistency.

Table .2: Reliability test results

\begin{tabular}{ll}
\hline Factor & Cronbach's alpha \\
\hline Value Co-Creation (VC) &. $\mathbf{9 2 6}$ \\
\hline Positive E-WOM (EW) &. $\mathbf{9 2 8}$ \\
\hline Brand Awareness (BA) & $\mathbf{. 8 7 5}$ \\
\hline Perceived Quality (PQ) & $\mathbf{. 8 9 4}$ \\
\hline Brand Loyalty (BL) & $\mathbf{. 8 6 9}$
\end{tabular}

Convergent validity was tested by looking at the estimate, all of which were significant (Bagozzi and Yi, 1988). Exploratory Factor Analysis (EFA) and Confirmatory Factor Analysis (CFA) were conducted to understand the data in hand. The AVE and the composite reliability CR for each construct are presented in Table 2. The results presents that the convergent validity was confirmed after deleting one cross loading item from the factor value co-creation since the results of AVE are all greater than 0.5 and the results of CR are greater than 0.7 (Fornell and larcker,1981)

Table. 3 Convergent Validity Testing Results

\begin{tabular}{lll}
\hline & CR & AVE \\
\hline Value co-creation & 0.915 & 0.578 \\
\hline Positive E-WOM & 0.929 & 0.765 \\
\hline Brand Awareness & 0.876 & 0.639 \\
\hline Perceived Quality & 0.895 & 0.740 \\
\hline Brand Loyalty & 0.870 & 0.691 \\
\hline
\end{tabular}

While Discriminant validity was tested using heterotrait-monotrait ratio of correlations (HTMT). The HTMT results on Table. 4 indicate that the Discriminant validity was confirmed since the results are all less than 0.95 (Henseler, Ringle, and Sarstedt, 2015)

Table.4 HTMT Results

\begin{tabular}{lllllll}
\hline & $\begin{array}{l}\text { Value } \\
\text { creation }\end{array}$ & co- & $\begin{array}{l}\text { Positive } \\
\text { WOM }\end{array}$ & $\begin{array}{l}\text { E- } \\
\text { Brand } \\
\text { Awareness }\end{array}$ & $\begin{array}{l}\text { Perceived } \\
\text { Quality }\end{array}$ & $\begin{array}{l}\text { Brand } \\
\text { Loyalty }\end{array}$ \\
\hline Value co-creation & - & & & & \\
\hline Positive E-WOM & 0.931 & - & - & - & \\
\hline Brand Awareness & 0.533 & 0.532 & 0.712 & & \\
\hline Perceived Quality & 0.4 & 0.402 & 0.8122 & 0.769 & - \\
\hline Brand Loyalty & 0.626 & 0.597 & 0.812 & \\
\hline
\end{tabular}


The model fit was appropriate $(\mathrm{CMIN} / \mathrm{DF}=2.746 \mathrm{p}$-value $=0.00 ; \mathrm{CFI}=0.933 ; \mathrm{RMSEA}=0.076 ; \mathrm{NFI}=0.900 ; \mathrm{IFI}=$ $0.934 ; \mathrm{GFI}=0.854$ ). Looking at several fit indices and taken together as suggested by the literature on global fit indices, the results indicates that the model fit is acceptable.

Second, the structural model (in Figure 1) was assessed to test the hypothesized relationships. The model fit was appropriate $(\mathrm{CMIN} / \mathrm{DF}=2.731 \mathrm{p}$-value $=0.00 ; \mathrm{CFI}=0.933 ; \mathrm{RMSEA}=0.076 ; \mathrm{NFI}=0.899 ; \mathrm{IFI}=0.933 ; \mathrm{GFI}=$ 0.854). The model fit is acceptable taken several fit indices together as suggested by the literature on global fit indices.

The hypotheses testing results are presented on table.5. The results shows that all hypotheses $\mathrm{H} 1, \mathrm{H} 2, \mathrm{H} 3$, and $\mathrm{H} 4$ were accepted. Value co-creation influence positive E-WOM and positive E-WOM influence brand awareness, perceived quality, and brand loyalty.

Table.5 Hypotheses Testing Results

\begin{tabular}{llllllll}
\hline \multicolumn{7}{c}{ Direct effect } & $Y<---X$ \\
\hline H1 & EW & $<---$ & VC & 0.939 & $* * *$ & Accepted \\
\hline H2 & BA & $<---$ & EW & 0.517 & $* * *$ & Accepted \\
\hline H3 & PQ & $<---$ & EW & 0.390 & $* * *$ & Accepted \\
\hline H4 & BL & $<---$ & EW & 0.606 & $* * *$ & Accepted \\
\hline$* * *=P<0.001$ & & & & &
\end{tabular}

The mediation relationships results in this model are presented on table.6. The results show that E-WOM does not mediate the relationship between value co-creation and brand equity. Therefore, $\mathrm{H} 5$ was rejected.

Table.6 Mediation Effects

\begin{tabular}{llll}
\hline \multicolumn{3}{c}{ Direct effect $Y<---X$} & Indirect effect \\
\hline BE $<---$ EW $<---V C$ & 0.234 (NS) & 0,349 (NS) & No mediation \\
\hline (NS) $=$ not significant & &
\end{tabular}

\section{Discussion}

The results indicated that when positive E-WOM is in control, the path coefficient of value co-creation and brand equity decrease but still remains significant. This means that positive E-WOM partially mediates the relation between value co-creation and brand equity. Therefore the hypothesis positive E-WOM mediates the relation between Value-co creation and brand equity, was accepted.

The result indicates that organizations can build brand equity by applying the concept of value co-creation in encouraging consumers to share positive E-WOM through organizations social media platforms. The current finding supplemented with previous research (Brodie et al., 2006) proving that creating value-added experiences for customers is viewed as a focal issue in managing the customer-brand relationship. The research results indicated that brand managers should fulfill customers' social interactions needs through the use of their social media activities, to create customers value to ensure that customers will communicate positively through organizations social platforms and thus establish a long-term relationship with the brand. 


\section{Conclusion}

The current research investigated the relationships between value co-creation, positive E-WOM, and brand equity. The research presented a conceptual model in order to conduct an empirical research to test the influence of value co-creation and positive E-WOM on brand equity. The results show that E-WOM does not mediate the relationship between value co-creation and brand equity. Value co-creation influence positive EWOM and positive E-WOM influence brand awareness, perceived quality, and brand loyalty.

\section{Limitation and Future studies}

The limitation is associated with the sampling approach used in this research. Specifically, it uses convenience sampling to collect the data through online forms. The adoption of non-probability sampling reduces the generalizability of the findings. Therefore, it is recommended that future research should replicate this research using a probability sampling technic directly recruiting participants.

\section{References}

1. Aaker, D.A. (1991). Managing Brand Equity: Capitalizing on the Value of a Brand Name, the Free Press. New York, NY

2. Anderson, E.W. (1998). Customer satisfaction and Word-of Mouth. Journal of Service Research, 1(1), 5-17.

3. Bagozzi, R. P., \& Yi, Y. (1988). On the evaluation of structural equation models. Journal of the academy of marketing science, $16(1), 74-94$.

4. Buil,I.,de Chernatony,L.\& Martínez ,E.(2008). Across-national validation of the consumer-based brand equity scale. Journal of Product \& Brand Management, 17(6), 384-392.

5. Buil, I., de Chernatony, L. \& Martínez, E. (2013). Examining the role of advertising and sales promotions in brand equity creation. Journal of Business Research, 66(1), 115-122.

6. Bowden, J. L. H. (2009). The process of customer engagement: a conceptual framework. The Journal of Marketing Theory and Practice, 17(1), 63-74

7. Brodie, R. J., Glynn, M. S., \& Little, V. (2006). The service brand and the service-dominant logic: missing fundamental premise or the need for stronger theory? Marketing Theory, 6(3), 363-379.

8. Brodie, R. J., Hollebeek, L. D., Jurić, B., \& Ilić, A. (2011). Customer engagement: Conceptual domain, fundamental propositions, and implications for research. Journal of Service Research, 14(3), 252-271.

9. Cheng, J. M. S., Wang, E. S. T., Lin, J. Y. C., \& Vivek, S. D. (2009). Why do customers utilize the internet as a retailing platform? A view from consumer perceived value. Asia Pacific Journal of Marketing and Logistics, 21(1), 144-160.

10. Dabholkar, Pratibha (1990). How to Improve Perceived Service Quality by Improving Customer Participation in Development in Marketing Science, B.J. Dunlap (Ed.). Cullowhee, NC: Academy of Marketing Science.

11. Dellarocas, C. (2003). The digitization of word of mouth: Promise and challenges of online feedback mechanisms. Management science, 49(10), 1407-1424.

12. Dong, B., Evans, K. R., \& Zou, S. (2008). The effects of customer participation in co-created service recovery. Journal of the Academy of Marketing Science, 36(1), 123-137. 
13. Fellesson, M., Salomonson, N. (2016). The expected retail customer: Value co-creator, co-producer or disturbance? Journal of Retailing and Consumer Services, 30, $204-211$.

14. Fornell, C., \& Larcker, D. F. (1981). Structural equation models with unobservable variables and measurement error: Algebra and statistics.

15. Gerbing, D. W., \& Anderson, J. C. (1988). An updated paradigm for scale development incorporating unidimensionality and its assessment. Journal of marketing research, 25(2), 186-192.

16. Gummerus, J., Liljander, V., Weman, E., \& Pihlström, M. (2012). Customer engagement in a Facebook brand community. Management Research Review, 35(9), 857-877

17. Glassman, M., \& McAfee, R. B. (1990). Enthusiasm: the missing link in leadership. SAM Advanced Management Journal, 55(3), 4-6.

18. Hajli, N., Lin, X., Featherman, M. S., \& Wang, Y. (2014). Social word of mouth: how trust develops in the market. International Journal of Market Research, 56(5), 673-689.

19. Haywood, K.M. (1989). Managing Word of Mouth communications. The Journal of Services Marketing, $3(2), 55-67$.

20. Hennig-Thurau, T., Gwinner, K. P., Walsh, G., \& Gremler, D. D. (2004). Electronic word-of-mouth via consumer-opinion platforms: What motivates consumers to articulate themselves on the Internet? Journal of Interactive Marketing, 18 (1), 38-52.

21. Henseler, J., Ringle, C. M., \& Sarstedt, M. (2015). A new criterion for assessing discriminant validity in variance-based structural equation modeling. Journal of the academy of marketing science, 43(1), 115-135.

22. Hollebeek, L. D. (2013). The customer engagement/value interface: an exploratory investigation. Australasian Marketing Journal (AMJ), 21(1), 17-24.

23. Hollebeek, L. D., Glynn, M. S., \& Brodie, R. J. (2014). Consumer brand engagement in social media: conceptualization, scale development and validation. Journal of Interactive Marketing, 28(2), 149-165.

24. Hu, Sh. W. (2013). Adding Value to Customer Relationship Management via Social Media. Bachelor Thesis, Kymenl Aakson Amattikorkekoulu University of applied science.

25. Jaakkola, E., \& Alexander, M. (2014). The role of customer engagement behavior in value Co-Creation a service system perspective. Journal of Service Research, 17(3), 247-261.

26. Kaplan, A. M., \& Haenlein, M. (2010). Users of the world, unite! The challenges and opportunities of Social Media. Business Horizons, 53(1), 59-68.

27. Keller, K.L. (2008), Strategic Brand Management: Building, Measuring, and Managing Brand Equity, 3d ed., Prentice Hall, Upper Saddle River, NJ.

28. Keller, K.L. (1993). Conceptualizing, measuring, and managing customer-based brand equity. Journal of Marketing, 57(1), 1-22.

29. Kotler, P., \& Keller, K. (2012). Marketing management (14th ed.). Upper Saddle River, NJ: Prentice Hall.

30. Lanier, C., \& Hampton, R. (2008). Consumer participation and experiential marketing: understanding the relationship between co-creation and the fantasy life cycle. Advances in Consumer Research, 35(1), 44-48. 
31. Lee, M., Rodgers, S., \& Kim, M. (2009). Effects of valence and extremity of e-WOM on attitude toward the brand and website. Journal of Current Issues and Research in Advertising, 31(2), 1-11.

32. Litvin, S.W., Goldsmith, R.E. \& Pan, B. (2008). Electronic word-of-mouth in hospitality and tourism management. Tourism Management, 29(3), 458-68.

33. Munjal, P; Mishra, M; and Shanker, R. (2019). The Drivers and Outcomes of Customer Engagement in Brand Communities. Journal of Management Research Vol. 19, No. 1, January-March 2019, pp. 56-76. DOI: 10.5958/0974-455X.2019.00005.2

34. Muniz Jr, A. M., \& O'guinn, T. C. (2001). Brand community. Journal of Consumer Research, 27(4), 412-432.

35. Netemeyer, R.G., Krishnan, B., Pullig, C., Wang, G., Yagci, M., Dean, D., Ricks, J. \& Wirth, F. (2004). Developing and validating measures of facets of customer-based brand equity. Journal of Business Research, 57(2), 209-224.

36. Ng, I. C. L., Nudurupati, S. S., \& Tasker, P. (2010). Value co-creation in the delivery of outcome-based contracts for business-to-business service. AIM Research Working Paper Series.

37. Nunnally, J. C., \& Bernstein, I. H. (1994). Psychometric theory. (3rd ed.). New York: McGraw-Hill

38. Otchere, S.\& Yun, T. (2019).The Effect of Value Co-creation on Innovation Performance: The Mediating Role of Customer Perceived Value. European Journal of Business and Management, 11(27), 47-55. DOI: 10.7176/EJBM

39. Payne, A. F., Storbacka, K., \& Frow, P. (2008). Managing the co-creation of value. Journal of the Academy of Marketing Science, 36(1), 83-96.

40. Patterson, P., Yu, T., \& De Ruyter, K. (2006). Understanding customer engagement in services. Advancing theory, maintaining relevance, proceedings of ANZMAC2006 conference, Brisbane, 4-6.

41. Prahalad, C. K., \& Ramaswamy, V. (2004). Co-creation experiences: The next practice in value creation. Journal of interactive marketing, 18(3), 5-14.

42. Prahalad, C. K., \& Ramaswamy, V. (2004a). The future of competition: Co-creating unique value with customers. Boston, MA: Harvard Business School Press.

43. Saleh, M. A. H. (2016). Social Networks and Customer Relationship Development at the Saudi Telecommunication Service Providers. International Journal of Marketing Studies, 8(4), 77.

44. Teeni, D. (2001). Review: a cognitive-affective model of organizational communication for designing IT. MIS Quarterly, 25(2), 251-312.

45. Vargo, S. L., Maglio, P. P., \& Akaka, M. A. (2008). On value and value co-creation: A service systems and service logic perspective. European Management Journal, 26(3), 145-152.

46. Vivek, S. D., Beatty, S. E., \& Morgan, R. M. (2012). Customer engagement: Exploring customer relationships beyond purchase. Journal of Marketing Theory and Practice, 20(2), 122-146.

47. Vivek, S.D. (2009). A scale of consumer engagement (Doctoral dissertation, The University of Alabama TUSCALOOSA).

48. Wigmo, J., \& Wikström, E. (2010). What Role Can Social Media Play as a Marketing Tool? Bachelor Thesis, Linnaeus University. 
49. $W u$, L.-C., \& Wu, L.-H. (2011). Service engineering: An interdisciplinary framework. The Journal of Computer Information Systems, 51(2), 14-23.

50. Yu, J., Zo, H., Choi, M. K., \& Ciganek, A. P. (2013). User acceptance of location-based social networking services: an extended perspective of perceived value. Online Information Review, 37(5), 711-730.

51. Zhang, M., Guo, L., Hu, M., \& Liu, W. (2017). Influence of customer engagement with company social networks on stickiness: Mediating effect of customer value creation. International Journal of Information Management, 37(3), 229-240. 